\title{
Total Numbers of Undiagnosed Carriers of Hepatitis C and B Viruses in Japan Estimated by Age- and Area-Specific Prevalence on the National Scale
}

\author{
Junko Tanaka ${ }^{a}$ Tomiko Koyamad ${ }^{d}$ Masaaki Mizui ${ }^{b}$ Shigeru Uchida ${ }^{f}$ \\ Keiko Katayama ${ }^{a}$ Junko Matsuo ${ }^{a}$ Tomoyuki Akita ${ }^{a}$ Ayumu Nakashima ${ }^{a}$ \\ Yuzo Miyakawa ${ }^{\mathrm{e}}$ Hiroshi Yoshizawac \\ ${ }^{a}$ Department of Epidemiology, Infectious Disease Control and Prevention, Hiroshima University Graduate School of \\ Biomedical Sciences, ${ }^{b}$ Japanese Red Cross Hiroshima Blood Center, and 'Hiroshima University, Hiroshima, \\ ${ }^{\mathrm{d}}$ Health Service Association, Iwate, ${ }^{e}$ Miyakawa Memorial Research Foundation, and ${ }^{\mathrm{f} J a p a n e s e}$ Red Cross Society \\ Blood Service Headquarters, Tokyo, Japan
}

\section{Key Words}

Hepatitis C virus - Hepatitis B virus - Blood donors - Liver cirrhosis $\cdot$ Hepatocellular carcinoma $\cdot$ Healthcare $\cdot$ Japan

\section{Abstract}

Objective: To estimate total numbers of undiagnosed carriers of hepatitis $C$ virus (HCV) and hepatitis B virus (HBV) in Japan. Methods: Area- and age-specific prevalence of HCV as well as HBV was determined in the first-time blood donors [20-39 years $(n=2,429,364)]$ and examinees of periodical health check-ups $[40-74$ years $(6,204,968$ for HCV and $6,228,967$ for HBV)] in Japan. Prevalence in adolescents [5-19 years $(79,256$ for HCV and 68,792 for HBV)] was determined in a single prefecture, and that of HCV in the elderly $(\geq 75$ years) was estimated by the exponential model. HBV infection was determined by the detection of hepatitis $B$ surface antigen, and HCV infection by either the algorithm or assuming persistent infection in $70 \%$ of the individuals with antibody to HCV. Results: Of the total population of 127,285,653 in $2005,807,903(95 \% \mathrm{Cl} 679,886-974,292)$ were estimated to be infected with HCV at a carrier rate of $0.63 \%$, and 903,145 $(837,189-969,572)$ with HBV at that of $0.71 \%$. Conclusion: Ac- curate estimation of undiagnosed HCV and HBV carriers in the general population would help to predict the future burden of liver disease, and take appropriate measures for improving healthcare.

Copyright $\odot 2011$ S. Karger AG, Basel

\section{Introduction}

Hepatitis $\mathrm{C}$ virus (HCV) and hepatitis B virus (HBV) are estimated to infect 170 and 350 million people over the world, respectively $[1,2]$. Most infections with HCV or HBV do not induce clinical liver disease, while $\sim 30 \%$ of them develop severe liver disease such as cirrhosis and hepatocellular carcinoma $[3,4]$. Hence, there is a pressing need to identify the individuals who have undiagnosed $\mathrm{HCV}$ or HBV infection, and take effective measures for terminating viral infections and preventing the progression of liver disease.

For management of persistent $\mathrm{HCV}$ and $\mathrm{HBV}$ infections in a given country, it is necessary to know their exact numbers for assessing medical and financial needs in the foreseeable future. Prevalence of undiagnosed HCV or HBV

\section{KARGER}

Fax +4161306 1234

E-Mail karger@karger.ch

www.karger.com
C 2011 S. Karger AG, Basel

$0300-5526 / 11 / 0544-0185 \$ 38.00 / 0$

Accessible online at:

www.karger.com/int
Junko Tanaka

Department of Epidemiology, Infectious Disease Control and Prevention

Hiroshima University Graduate School of Biomedical Sciences

1-2-3 Kasumi, Minami-ku, Hiroshima 734-8551 (Japan)

Tel. +81 82257 5161, E-Mail jun-tanaka@ hiroshima-u.ac.jp 
infection has been estimated by survey of blood donors in Japan [5] and a representative population in the USA [6].

In the present study, area- and age-specific prevalence of $\mathrm{HCV}$ or HBV infection was determined in 8 jurisdiction areas of the Japanese Red Cross Blood Center. Then, the total numbers of undiagnosed HBV and HCV infections were estimated by compiling the results in the firsttime blood donors and examinees of the periodical health check-up program. Of the 127,285,653 Japanese registered in $2005,807,903(0.63 \%)$ were estimated to be infected with HCV and 903,145 (0.71\%) with HBV.

\section{Materials and Methods}

\section{Japanese Population}

Japan is divided into 8 areas, along its north-to-south axis, according to jurisdiction of the Japanese Red Cross Blood Center, into Hokkaido, Tohoku, Kanto, Hokuriku/Tokai, Kinki, Chugoku, Shikoku and Kyushu. Populations in 5-year age groups in each jurisdiction area were obtained from the registry at the National Census 2005.

\section{First-Time Blood Donors}

During 6 years from January 2001 to December 2006, 3,748,422 individuals (aged 16-64 years) donated whole blood or apheresis products for the first time, and their sera were tested for markers of HCV and HBV infections. Ongoing HCV infection was estimated by assuming the detection of HCV RNA in $70 \%$ of individuals with the antibody to HCV (anti-HCV), in accordance with a previous report [5].

\section{Examinees of Hepatitis Virus Infections}

Since the fiscal year 2002 in Japan, individuals who turned 40, $45,50,55,60,65$ and 70 years were offered to take tests for hepatitis viruses at periodical health check-ups by a 5 -year national project. During 5 years through 2006, 6,204,968 individuals received tests for $\mathrm{HCV}$ and $6,228,967$ for $\mathrm{HBV}$, corresponding to $\sim 30 \%$ of the eligible Japanese, and their area- and age-specific prevalence of $\mathrm{HCV}$ or $\mathrm{HBV}$ infection was determined.

\section{School Children and Adolescents}

In the Iwate prefecture located in the north of Japan, biochemical markers of diseases dependent on the lifestyle were examined in children and adolescents at the entrance to schools. Their serum samples had been stored frozen, and were tested for markers of hepatitis virus infections. Carrier rates of $\mathrm{HCV}$ and $\mathrm{HBV}$ among them were calculated, with their ages adjusted to those in 2005 ; infants aged $<5$ were represented by the children aged from 5 to 9 years. Designs and procedures of this investigation were approved by the Ethics Committee of Hiroshima University.

\section{Simulation of HCV and HBV Infections in the Elderly}

By its age-specific profile, the prevalence of $\mathrm{HCV}$ was deduced to be an exponential function of the age. Accordingly, age-specific prevalence of $\mathrm{HCV}$ in the individuals aged $\geq 75$ years was simulated by an exponential function model; it was constructed on the prevalence of $\mathrm{HCV}$ in each age group $\geq 50$ years.
The formula was constructed as:

$$
\log y(x)=a+b x
$$

where $x$ is the 5 -year age code, $y(x)$ is an estimator of HCV prevalence in $x$, and $a$ and $b$ are coefficients.

The equation is transformed into:

$$
y(x)=\mathrm{e}^{a} \mathrm{e}^{b x}
$$

in which $\mathrm{e}^{a}$ represents the HCV prevalence when $x=0$ (in the group aged $0-4$ years), since $y(0)$ is equal to $\mathrm{e}^{a}$. By replacing $x$ for $x+1$ in the above equation, it is converted to $y(x+1)=\mathrm{e}^{a} \mathrm{e}^{b(x+1)}$.

Then, the following equation can be constructed:

$$
y(x+1)=\mathrm{e}^{b} y(x)
$$

where $\mathrm{e}^{b}$ is the slope of HCV prevalence increasing with age. Thus, the HCV prevalence is multiplied by a factor $\mathrm{e}^{b}$ for an increment of the age code by 1 .

The simulation model was applied to estimate age-specific prevalence of $\mathrm{HCV}$ in each of 8 areas in the individuals $\geq 75$ years.

Prevalence of $\mathrm{HBV}$ in the individuals $\geq 75$ years was represented by that in those aged 70-74 years, since it stayed constant from 65 through 75 years.

\section{Markers of Hepatitis Virus Infections}

In blood donors, anti-HCV was determined by passive hemagglutination of the second generation with commercial assay kits (HCV PHA; Abbott Laboratories, North Chicago, Ill., USA) with a cutoff limit set at $2^{5}$, as well as by particle agglutination with commercial assay kits (HCV PA Test-II; Fujirebio, Inc., Tokyo, Japan). HBsAg was determined by reversed passive hemagglutination with reagents prepared by the Japanese Red Cross.

In examinees of periodical health check-ups, ongoing HCV infection was determined by the algorithm with anti-HCV and HCV RNA [7]. Anti-HCV was determined by passive hemagglutination of the second generation with commercial assay kits (HCV PHA; Abbott Laboratories), and since 2002, it was determined by enzyme immunoassay with commercial assay kits (AxSYM HCV Dinapack-III; Abbott Laboratories). Samples with high anti-HCV titers contain HCV RNA, and therefore, only those with low and middle titers were examined for HCV RNA. HBsAg was determined by reversed-passive hemagglutination with commercial assay kits (Institute of Immunology Co., Ltd, Tokyo, Japan).

Statistical Analyses

Statistical analyses for the evaluation of $\mathrm{R}^{2}$ values were performed with JMP 8.0 (SAS Institute, Inc., Cary, N.C., USA) and DeltaGraph 5.5 (RedRock Software, Inc., Salt Lake City, Utah, USA). A p value $>0.05$ was considered significant.

\section{Results}

Age-Specific Prevalence of HCV in the First-Time Blood Donors and Examinees of Periodical Health Check-Ups

Figure 1 illustrates age-specific prevalence of $\mathrm{HCV}$ in the first-time blood donors (aged 15-69 years in 2005) and examinees of periodical health check-ups (39-73 years in 2005); $70 \%$ of individuals with anti-HCV were considered 


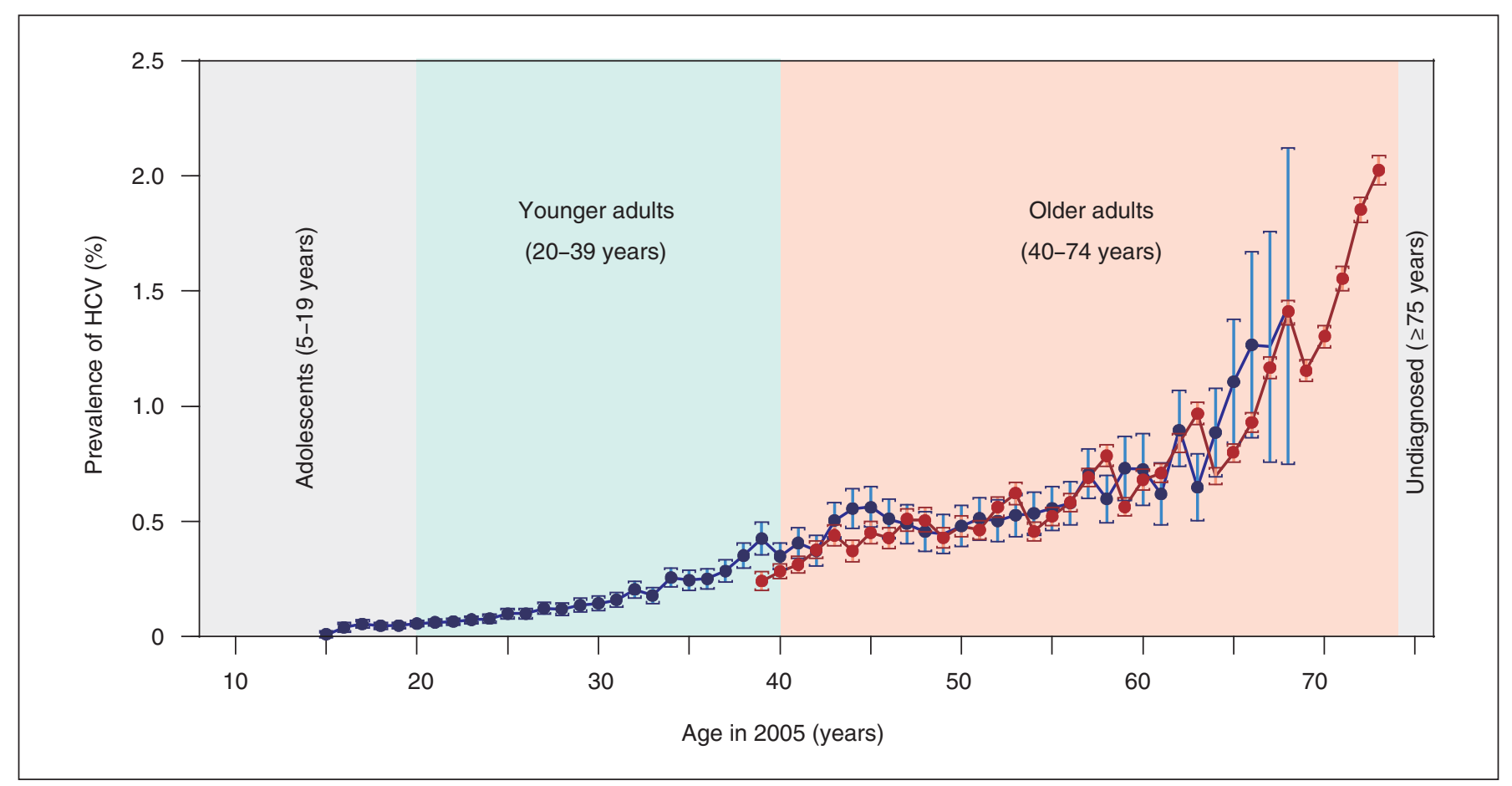

Fig. 1. Age-specific prevalence of HCV in Japan. The prevalence of HCV was determined in the first-time blood donors aged from 15 to 68 years (blue dots) and examinees of periodical health check-ups aged from 39 to 73 years (red dots). Their ages were adjusted to those in the year 2005. Bars indicate ranges of 95\% CI.

to possess HCV RNA in serum [5]. Results of two distinct populations were well in accord. For the first-time blood donors, however, the variation (95\% CI) widened increasingly with age. It would have reflected decreases in the first-time blood donors with age, since the majority of these $(83.5 \%)$ were aged $\leq 39$ years. As the prevalence of $\mathrm{HCV}$ in blood donors $\geq 40$ years was unreliable in them, that in examinees of periodical check-ups was adopted for estimating the national prevalence of $\mathrm{HCV}$.

\section{Area-Specific Prevalence of HCV in Eight Jurisdiction} Areas

In view of distinct geographic distribution of $\mathrm{HCV}$, the prevalence of $\mathrm{HCV}$ in the general population would not be applicable to every area in Japan. Figure 2 compares results in the first-time blood donors and recipients of health check-ups among 8 jurisdiction areas spanning from north (Hokkaido) to south (Kyushu). They unfolded a wide variety in the age-specific prevalence of HCV. Although the prevalence of HCV increased with age in all areas, the slope of increase differed widely among them. Hence, it was necessary to employ a distinct age-specific prevalence in each of the 8 areas for estimating HCV carriers precisely.
Table 1. Age-specific prevalence of HCV in three different populations

\begin{tabular}{crrl}
\hline Age in 2005 & $\mathrm{n}$ & $\begin{array}{l}\mathrm{HCV}- \\
\text { positive, } \mathrm{n}\end{array}$ & $\begin{array}{l}\text { Prevalence, } \% \\
(95 \% \mathrm{CI})\end{array}$ \\
\hline $\begin{array}{c}\text { School children } \\
5-9\end{array}$ & 17,390 & 2 & $0.012(0.000-0.027)$ \\
$10-14$ & 29,817 & 3 & $0.010(0.000-0.021)$ \\
$15-19$ & 32,049 & 7 & $0.022(0.006-0.038)$ \\
\hline Blood donors & & & \\
$20-24$ & $1,205,966$ & 1,122 & $0.065(0.061-0.070)^{\mathrm{a}}$ \\
$25-29$ & 536,560 & 874 & $0.114(0.105-0.123)^{\mathrm{a}}$ \\
$30-34$ & 408,814 & 1,089 & $0.186(0.173-0.200)^{\mathrm{a}}$ \\
$35-39$ & 278,024 & 1,190 & $0.300(0.279-0.320)^{\mathrm{a}}$ \\
\hline HCV screening & & & \\
$40-44$ & 611,146 & 2,127 & $0.348(0.333-0.363)$ \\
$45-49$ & 495,032 & 2,292 & $0.463(0.444-0.482)$ \\
$50-54$ & 675,350 & 3,485 & $0.516(0.499-0.533)$ \\
$55-59$ & 947,438 & 5,974 & $0.631(0.615-0.646)$ \\
$60-64$ & $1,081,854$ & 8,423 & $0.779(0.762-0.795)$ \\
$65-69$ & $1,264,496$ & 13,722 & $1.085(1.067-1.103)$ \\
$70-74$ & $1,054,472$ & 17,649 & $1.674(1.649-1.698)$
\end{tabular}

a The prevalence in blood donors was based on an assumption of HCV infection persisting in $70 \%$ of those with anti-HCV [5]. 

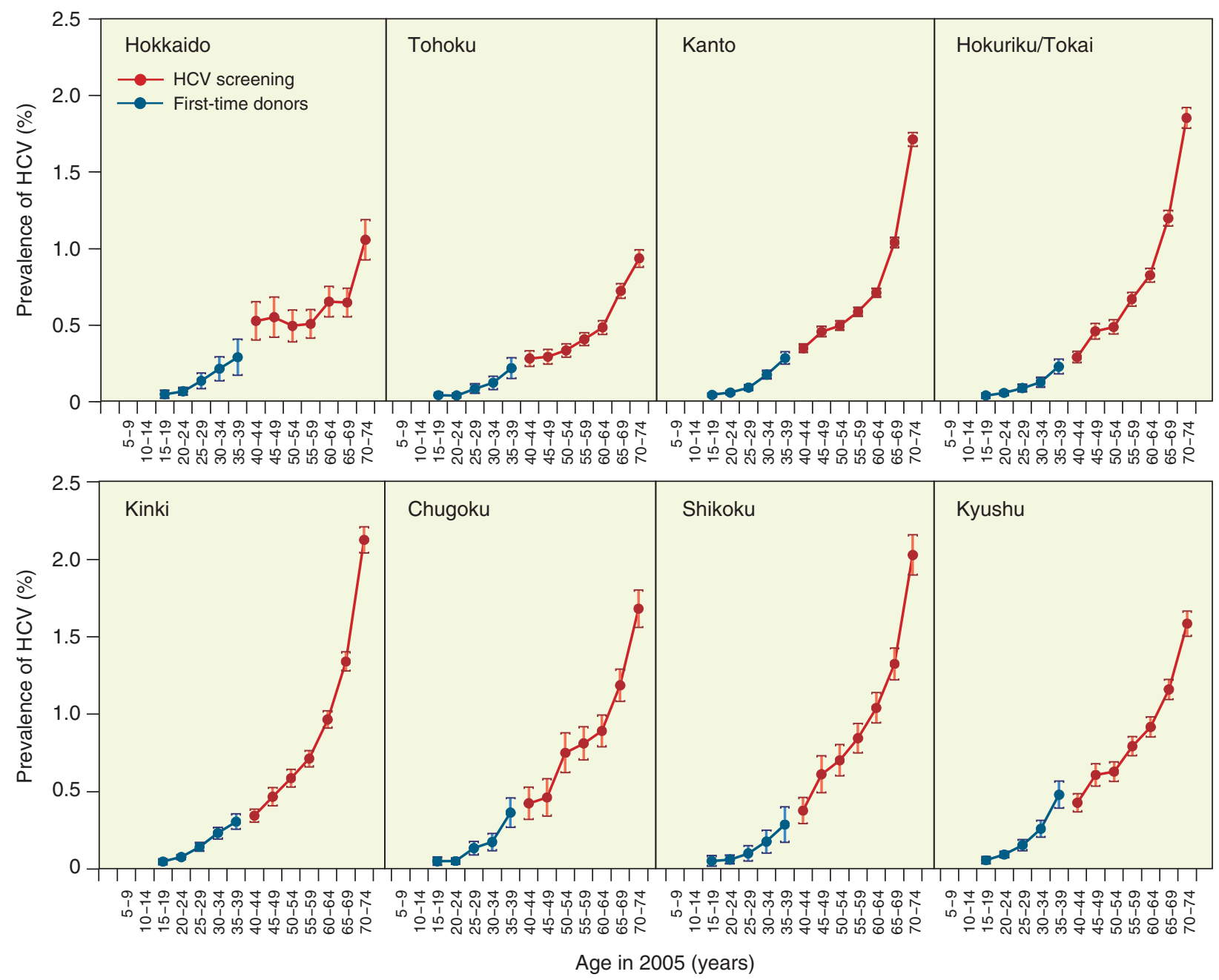

Fig. 2. Age-specific prevalence of HCV in 8 jurisdiction areas in Japan. The prevalence of HCV is calculated in each of twelve age groups notched by 5 years. The prevalence in five groups $\leq 39$ years was represented by the first-time blood donors, and that in seven groups $\geq 40$ years by recipients of HCV screening. Bars indicate ranges of $95 \% \mathrm{CI}$.

\section{Prevalence of HCV in Adolescents}

Since blood donors were restricted to $16-64$ years of age, and health examinees were targeted on $40-70$ years, they did not cover individuals aged $\leq 15$ or $\geq 75$ years in the year 2005. To fill in an opening on the younger side, the age-specific prevalence of HCV was determined in school children and adolescents in the Iwate prefecture (table 1). The prevalence in infants aged $0-4$ years was assumed similar to that in the children aged 5-9 years; an extremely low prevalence of HCV (0.012\%) would support such an assumption.

\section{Simulating Prevalence of HCV in the Elderly}

The prevalence of HCV appeared to be an exponential function of the age, according to its profiles in the firsttime blood donors and examinees of health check-ups (fig. 1). Based on this assumption, a formula was constructed to simulate the prevalence of $\mathrm{HCV}$ in age groups $\geq 75$ years for each of the 8 jurisdiction areas in Japan (see Materials and Methods).

Figure 3 compares actual (dots) and simulated data (red line) of five age groups from 50 to 74 years (corresponding to age codes 10-14) among the 8 areas. There was a high coefficient of determination between them, 


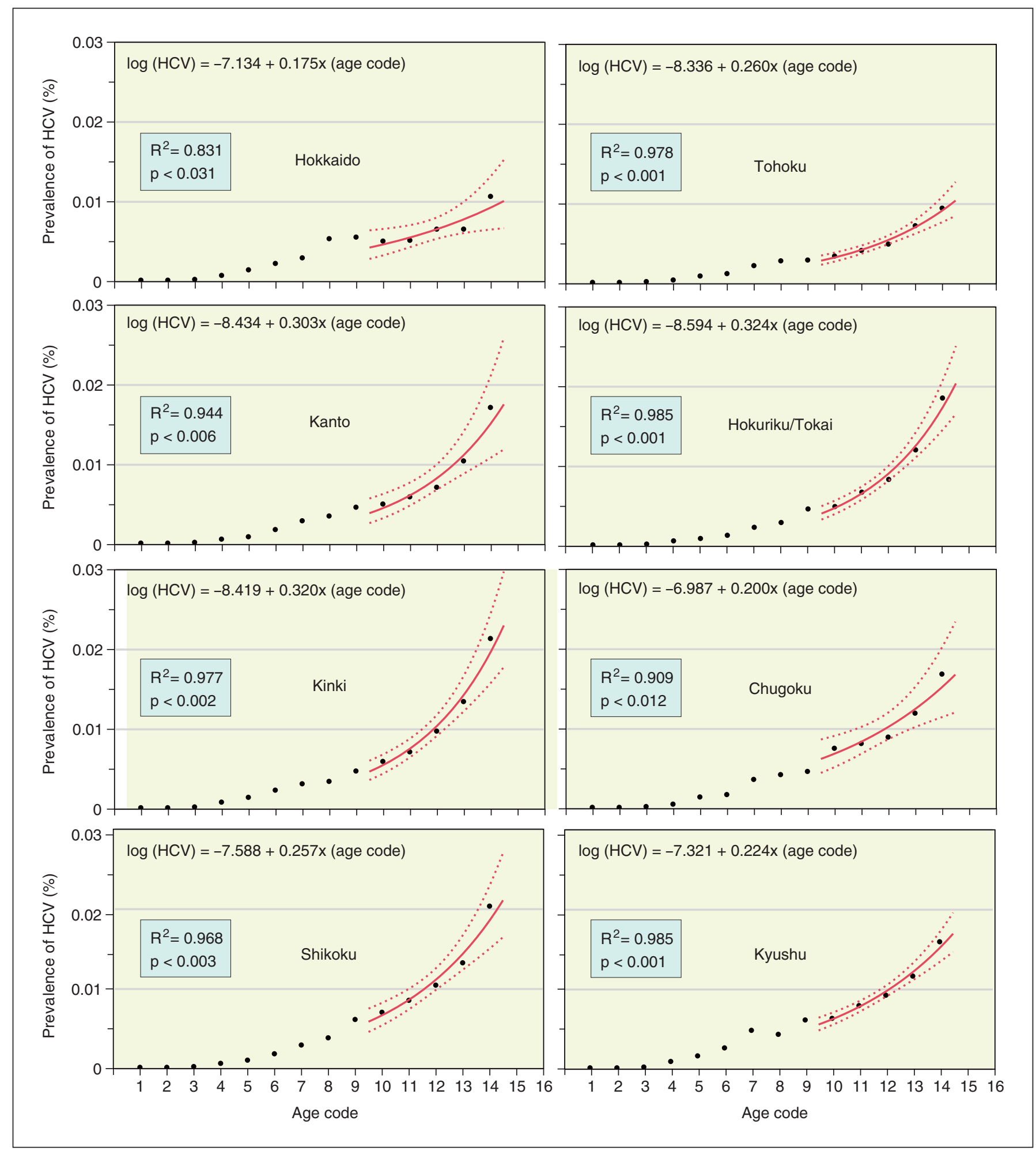

Fig. 3. Simulation of age-specific prevalence of HCV in the elderly. Prevalence of HCV in the first-time blood donors as well as examinees of periodical health check-ups (dots) and that simulated by formulation (red line with ranges of $95 \%$ CI in dotted line) are shown for 8 jurisdiction areas in Japan. Formula is shown at the top of each area. Age codes are: 1, 5-9 years; 2, 10-14 years; 3, $15-19$ years; $4,20-24$ years; $5,25-29$ years; 6,30 - 34 years; $7,35-39$ years; $8,40-44$ years; $9,45-49$ years; $10,50-54$ years; $11,55-59$ years; $12,60-64$ years; $13,65-69$ years; $14,70-74$ years, and 15, $75-79$ years. 
Table 2. Regional and total HCV carriers in Japan

\begin{tabular}{lrcl}
\hline Areas & Population & HCV carriers $(95 \%$ CI $)$ & Carrier rate \\
\hline Hokkaido & $5,620,813$ & $26,097(19,356-34,413)$ & $0.46 \%$ \\
Tohoku & $12,047,975$ & $50,688(42,754-59,953)$ & $0.40 \%$ \\
Kanto & $41,247,892$ & $235,328(195,408-293,611)$ & $0.57 \%$ \\
Hokuriku/Tokai & $19,294,443$ & $132,434(114,216-154,446)$ & $0.69 \%$ \\
Kinki & $22,657,542$ & $173,808(147,548-207,173)$ & $0.52 \%$ \\
Chugoku & $7,650,977$ & $53,296(42,299-67,698)$ & $0.70 \%$ \\
Shikoku & $4,083,698$ & $35,159(28,746-43,004)$ & $0.86 \%$ \\
Kyushu & $14,682,313$ & $101,092(89,379-113,993)$ & $0.80 \%$ \\
\hline Total & $127,285,653$ & $807,903(679,886-974,292)$ & $0.63 \%$ \\
\hline
\end{tabular}

Table 3. Age-specific prevalence of $\mathrm{HBV}$ in three different populations

\begin{tabular}{crrr}
\hline Age in 2005 & $\mathrm{n}$ & HBV-positive, $\mathrm{n}$ & Prevalence, \% (95\% CI) \\
\hline $\begin{array}{c}\text { School children } \\
5-9\end{array}$ & 17,363 & 3 & \\
$10-14$ & 29,817 & 14 & $0.017(0.000-0.037)$ \\
$15-19$ & 32,049 & 12 & $0.047(0.022-0.072)$ \\
\hline Blood donors & & & \\
$20-24$ & $1,205,966$ & 1,826 & $0.151(0.144-0.158)$ \\
$25-29$ & 536,560 & 1,650 & $0.308(0.293-0.322)$ \\
$30-34$ & 408,814 & 1,759 & $0.430(0.410-0.450)$ \\
$35-39$ & 278,024 & 1,327 & $0.477(0.452-0.503)$ \\
\hline HBV screening & & & \\
$40-44$ & 613,960 & 5,491 & $0.894(0.871-0.918)$ \\
$45-49$ & 497,589 & 5,373 & $1.080(1.051-1.109)$ \\
$50-54$ & 679,893 & 8,700 & $1.280(1.253-1.306)$ \\
$55-59$ & 950,508 & 12,891 & $1.356(1.333-1.379)$ \\
$60-64$ & $1,085,119$ & 13,282 & $1.224(1.203-1.245)$ \\
$65-69$ & $1,268,304$ & 12,406 & $0.978(0.961-0.995)$ \\
$70-74$ & $1,057,469$ & 9,545 & $0.903(0.885-0.921)$ \\
\hline
\end{tabular}

with $\mathrm{R}^{2}$ values ranging from 0.831 to 0.985 ( $\mathrm{p}<0.031$ and $\mathrm{p}<0.001$, respectively), attesting to the validity of this simulation. Of note, the factor $b$ in formula (by which age codes were multiplied) varied broadly among the 8 areas. Thus, it was the highest in Hokuriku/Tokai at 0.324 and lowest in Hokkaido at 0.175, with close to twofold differences between them.

\section{Estimation of Undiagnosed HCV Carriers in Eight}

\section{Areas and the Entire Nation}

Based on age- and area-specific prevalence of HCV, numbers of undiagnosed HCV carriers were calculated for 8 jurisdiction areas, and they were compiled in the entire nation (table 2). The prevalence of $\mathrm{HCV}$ in each of three age groups (75-79, $80-84$ and $\geq 85$ years) was simulated by the formula, while that of HBV was represented by the prevalence in the group of 70-74 years. As of the year 2005, 127,285,653 were registered in the national census of Japan, and 807,903 of these are estimated to have undiagnosed HCV infection at an overall carrier rate of $0.63 \%$. There was an increasing gradient in the prevalence of HCV along the north-to-south axis of Japan.

\section{Age-Specific Prevalence of $\mathrm{HBV}$}

Figure 4 depicts age-specific prevalence of $\mathrm{HBV}$ in 2005. It was deduced from HBsAg in the first-time blood donors (15-69 years) and examinees of periodical health check-ups (39-73 years). Since the prevalence of HBV in the elderly did not increase with age so sharply as that of HCV (fig. 1), it was presumed not to increase further and stay around $1 \%$ in the individuals $\geq 75$ years. The agespecific prevalence of $\mathrm{HBV}$ tabulated in three different 


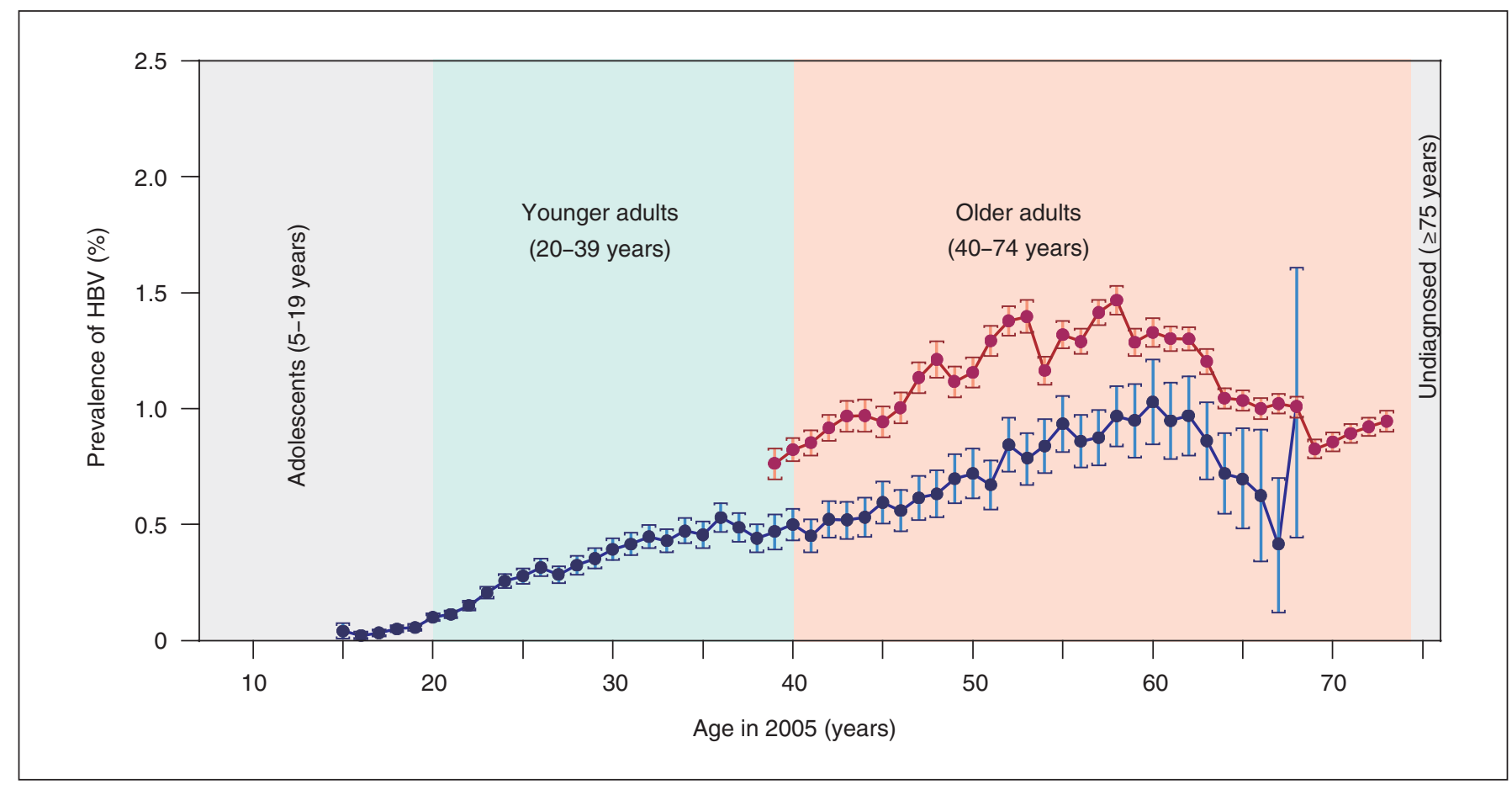

Fig. 4. Age-specific prevalence of HBV in Japan during 2002-2006. The prevalence of HBV was determined in the first-time blood donors aged from 15 to 68 years (blue dots) in the year 2005 and examinees of periodical health check-ups aged from 39 to 73 years (red dots) in the year 2005. Bars indicate ranges of 95\% CI.

populations is listed in table 3 . There was a constant decline with decreasing age in the frequency of HBV in individuals $\leq 39$ years, and it was particularly low in children $\leq 9$ years $(0.017 \%)$.

In examinees of periodical health check-ups, the agespecific prevalence of $\mathrm{HBV}$ did not diverge and stayed within a narrow 95\% CI (fig. 4). By contrast, that in the first-time blood donors dispersed widely. Such a variation in the age-specific prevalence of $\mathrm{HBV}$ would have been ascribed to the first-time blood donors who clustered in age groups $\leq 40$ years.

\section{Area-Specific Prevalence of HBV in Eight Jurisdiction} Areas

The age-specific prevalence of HBsAg varied widely among 8 jurisdiction areas (fig. 5). HBsAg was most frequent in the age group of 55-59 years in every area, and reached $3.1 \%$ in the northern-most Hokkaido. The peak frequency decreased in central Japan (1.1\% in Kanto and Hokuriku/Tokai), and increased towards the southern end (1.9\% in Kyushu). Thus, the prevalence of HBsAg was determined individually along the axis of Japan in estimating the total number of HBV carriers in Japan.

\section{Estimation of Undiagnosed HBV Carriers in Eight Areas and the Entire Nation}

Numbers of undiagnosed HBV carriers were complied by multiplying age-specific prevalence of HBsAg by corresponding subpopulations in 8 jurisdiction areas (table 4). In total, 903,145 of the $127,285,653$ (0.71\%) individuals are estimated to have undiagnosed HBV infection in Japan in 2005.

\section{Shift of Undiagnosed HCV and HBV Carriers during} 5 Years (2000-2005) in Japan

Table 5 compares numbers of HCV and HBV carriers aged 15-69 years between 2000 and 2005 for 8 jurisdiction areas in Japan. Data for the year 2000 were extracted from a previous survey [5]. Data for the year 2005 were obtained in the first-time blood donors during 2001-2006 in this study by the same method as in the previous survey [5]. Undiagnosed HCV and HBV carriers decreased during 5 years by 55 and $47.5 \%$, respectively. The overall carrier rate of HCV declined sharply from 0.95 to $0.44 \%$, and that of HBV from 1.04 to $0.55 \%$ in Japan. 

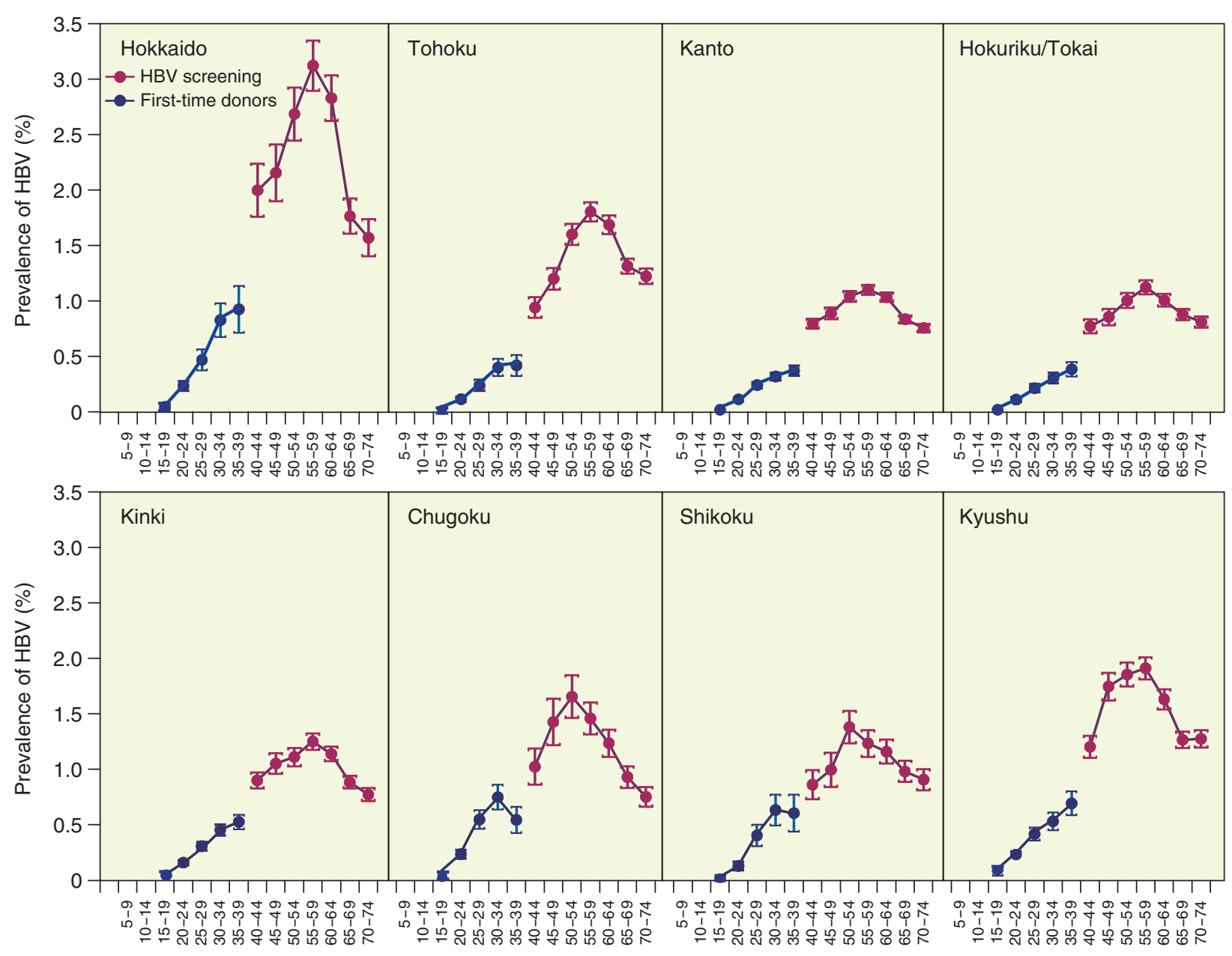

Age in 2005 (years)

Fig. 5. Age-specific prevalence of $\mathrm{HBV}$ in 8 jurisdiction areas in Japan. The prevalence of HBV is calculated in each of twelve age groups notched by 5 years. The prevalence in five groups $\leq 39$ years was represented by the first-time blood donors and that in seven groups $\geq 40$ years by recipients of HCV screening. Bars indicate ranges of $95 \%$ CI.

Table 4. Regional and total HBV carriers in Japan

\begin{tabular}{lrcc}
\hline Areas & Population & HBV carriers $(95 \%$ CI $)$ & Carrier rate \\
\hline Hokkaido & $5,620,813$ & $80,573(72,314-88,765)$ & $1.43 \%$ \\
Tohoku & $12,047,975$ & $104,736(97,742-111,816)$ & $0.87 \%$ \\
Kanto & $41,247,892$ & $231,799(220,129-244,105)$ & $0.56 \%$ \\
Hokuriku/Tokai & $19,294,443$ & $109,709(101,722-117,581)$ & $0.56 \%$ \\
Kinki & $22,657,542$ & $144,965(134,387-155,464)$ & $0.64 \%$ \\
Chugoku & $7,650,977$ & $59,948(52,705-67,121)$ & $0.78 \%$ \\
Shikoku & $4,083,698$ & $29,776(26,080-33,437)$ & $0.73 \%$ \\
Kyushu & $14,682,313$ & $141,639(132,111-151,282)$ & $0.96 \%$ \\
\hline Total & $127,285,653$ & $903,145(837,189-969,572)$ & $0.71 \%$ \\
\hline
\end{tabular}


Table 5. Decrease of undiagnosed HCV and HBV carriers in the 15- to 69-year-old population in Japan

\begin{tabular}{|c|c|c|c|c|c|c|}
\hline & \multicolumn{2}{|c|}{ Survey in $2000^{a}$} & \multicolumn{2}{|c|}{ Survey in 2005} & \multicolumn{2}{|l|}{ Difference } \\
\hline & $\begin{array}{l}\text { number } \\
\text { estimated }\end{array}$ & $\begin{array}{l}\text { carrier rate } \\
\text { in area }{ }^{b}\end{array}$ & $\begin{array}{l}\text { number } \\
\text { estimated }\end{array}$ & $\begin{array}{l}\text { carrier rate } \\
\text { in area }{ }^{b}\end{array}$ & $\begin{array}{l}\text { number } \\
\text { estimated }\end{array}$ & balance \\
\hline \multicolumn{7}{|c|}{ Shift of HCV carriers during 5 years from 2000 to 2005} \\
\hline Hokkaido & 41,139 & $0.99 \%$ & 17,658 & $0.44 \%$ & $-23,481$ & $-57.1 \%$ \\
\hline Tohoku & 61,658 & $0.71 \%$ & 30,525 & $0.37 \%$ & $-31,133$ & $-50.5 \%$ \\
\hline Kanto & 277,644 & $0.90 \%$ & 126,283 & $0.41 \%$ & $-151,361$ & $-54.5 \%$ \\
\hline Hokuriku/Tokai & 88,724 & $0.64 \%$ & 48,360 & $0.35 \%$ & $-40,364$ & $-45.5 \%$ \\
\hline Kinki & 178,871 & $1.06 \%$ & 70,526 & $0.43 \%$ & $-108,345$ & $-60.6 \%$ \\
\hline Chugoku & 72,431 & $1.32 \%$ & 24,595 & $0.47 \%$ & $-47,836$ & $-66.0 \%$ \\
\hline Shikoku & 43,497 & $1.49 \%$ & 16,504 & $0.59 \%$ & $-26,993$ & $-62.1 \%$ \\
\hline Kyushu & 120,989 & $1.16 \%$ & 64,115 & $0.63 \%$ & $-56,874$ & $-47.0 \%$ \\
\hline Total & 884,954 & $0.95 \%$ & 398,567 & $0.44 \%$ & $-486,387$ & $-55.0 \%$ \\
\hline \multicolumn{7}{|c|}{ Shift of HBV carriers during 5 years from 2000 to 2005} \\
\hline Hokkaido & 106,896 & $2.56 \%$ & 54,557 & $1.35 \%$ & $-52,339$ & $-49.0 \%$ \\
\hline Tohoku & 104,923 & $1.21 \%$ & 48,490 & $0.58 \%$ & $-56,433$ & $-53.8 \%$ \\
\hline Kanto & 255,207 & $0.83 \%$ & 132,414 & $0.43 \%$ & $-122,793$ & $-48.1 \%$ \\
\hline Hokuriku/Tokai & 78,481 & $0.56 \%$ & 51,477 & $0.37 \%$ & $-27,004$ & $-34.4 \%$ \\
\hline Kinki & 165,915 & $0.98 \%$ & 85,083 & $0.52 \%$ & $-80,832$ & $-48.7 \%$ \\
\hline Chugoku & 90,041 & $1.64 \%$ & 37,706 & $0.71 \%$ & $-52,335$ & $-58.1 \%$ \\
\hline Shikoku & 38,411 & $1.32 \%$ & 19,162 & $0.69 \%$ & $-19,249$ & $-50.1 \%$ \\
\hline Kyushu & 127,879 & $1.23 \%$ & 77,941 & $0.77 \%$ & $-49,938$ & $-39.1 \%$ \\
\hline Total & 967,753 & $1.04 \%$ & 506,830 & $0.55 \%$ & $-460,923$ & $-47.6 \%$ \\
\hline
\end{tabular}

\section{Discussion}

There are many constraints in estimating total $\mathrm{HCV}$ and HBV infections in a given nation. Since it is not feasible to test every member for serological markers of hepatitis virus infection, populations representative of the entire nation have served for the estimation. Volunteer blood donors are recruited, but they have a restricted age range (16-64 years in Japan). Students attending schools and universities can close the opening in younger generations, but infants younger than the school age are not enrolled. Moreover, there are no means of estimating carrier rates of hepatitis virus infections in the individuals aged beyond the eligibility of blood donation. In addition, blood donors are selected individuals who are leading healthy lives above the average. In the survey of inhabitants in sentinel counties of the USA [6], who represent the average Americans, patients with liver disease and persons with restricted activities, such as those incarcerated or institutionalized, are not included.

Undiagnosed HCV and HBV Carriers in Japan
Patients with clinical liver disease, as well as individuals found with HCV or HBV infection by health checkups, can receive the medical care. However, many blood donors found with viral infections have developed severe liver disease already, and therefore, cannot receive efficient medical interventions $[7,8]$. Hence, it is necessary to detect undiagnosed HCV and HBV infections hidden in the society. For this purpose, periodical health check-ups for screening hepatitis virus markers were started in April 2002 on the individuals, who turned 40, 45, 50, 55, 60 and 70 years, by a 5 -year national project in Japan. The target age range (40-70 years) was selected due to a high incidence of hepatocellular carcinoma [9]. Since by far the majority of the first-time blood donors were younger than 40 years, the prevalence of HCV or HBV beyond that age dispersed widely (fig. 1, 4). In this study, therefore, the coverage by the first-time blood donors was confined to 20-39 years of age, and it was taken place by examinees of health check-ups aged 40-74 years; they left age groups $\leq 15$ and $\geq 75$ years uncovered, however.

Intervirology 2011;54:185-195 
The national prevalence of hepatitis virus infections in individuals $\leq 19$ years was presumed to be similar to that in the Iwate prefecture situated in northern Japan. Since the prevalence of HCV or HBV infection in them was extremely low and stayed between 0.01 and $0.02 \%$, such an assumption would not have affected the overall results to any significant extent. The prevalence of $\mathrm{HCV}$ in age groups $\geq 75$ was simulated by a premise that it would be an exponential function of the age. Consequently, the formula based on profiles in five age groups from 50 to 74 years (at a 5-year notch) was extrapolated to three age groups $\geq 75$ years. The simulation matched closely with the prevalence determined in corresponding age groups, with $\mathrm{R}^{2}$ values ranging from 0.83 to 0.99 ( $\mathrm{p}<0.05$ and $\mathrm{p}<0.01$, respectively) throughout 8 jurisdiction areas in Japan (fig. 3).

Japan has an axis spanning 2,000 kilometers from the north-east towards the south-west over the four major islands (Hokkaido, Honshu, Shikoku and Kyushu). Within a rather small land, the prevalence of $\mathrm{HCV}$ or $\mathrm{HBV}$ is not uniform all over Japan. The prevalence of HCV had an increasing gradient from north to south, and was the highest in Kyushu (table 2), while that of HBV was the highest in Hokkaido, decreased in between and then increased towards Kyushu (table 4). Reflecting such local differences, age-specific prevalence of HCV or HBV differed widely among 8 jurisdiction areas (fig. 2, 5).

Based on the results obtained on the area- and agespecific prevalence of $\mathrm{HCV}$ or HBV, carriers of these hepatitis viruses in 8 jurisdiction areas were tabulated separately over age groups from 20 to 74 years. Those in age groups $\leq 19$ years were represented by the Iwate prefecture. The prevalence of $\mathrm{HCV}$ in age groups $\geq 75$ years was simulated by the formula, and that of HBV was represented by individuals aged 70-74 years. Japan was populated by $127,767,994$ people in 2005 . Of these, 807,903 (95\% CI 679,886-974,292) were estimated to have undiagnosed HCV infection at an overall prevalence of $0.63 \%$, and $903,145(837,189-969,572)$ to possess undiagnosed HBV infection at that of $0.71 \%$. These estimates are much less than publically inferred numbers of HCV and HBV carriers in Japan at 1.5-2.0 million each. Leaving aside $\mathrm{HCV}$ and HBV carriers who have developed liver disease and stayed outside the scope of the present study, our estimates based on reasonable scientific grounds are much smaller; they add up barely half of generally referred figures around 1.5-2.0 million in Japan.

Based on the sex- and age-specific prevalence of hepatitis virus markers in the 3,478,422 first-time blood donors during 2001-2006, with the same criteria used in the previous study [5], we have estimated the number of undiagnosed HCV carriers aged 15-69 years in the year 2005 to be 398,567 (95\% CI 295,410-501,453) and that of undiagnosed HBV carriers to be 506,830 (95\% CI398,115$616,113)$. In the previous study [5], undiagnosed HCV and HBV carriers aged 15-69 years in the year 2000 were assessed to be 884,954 (95\% CI 725,082-1,044,826) and those with HBV to be 967,753 (95\% CI 806,760-1,128,745). They decreased by 55.0 and $47.6 \%$, respectively, during 5 years (table 5). In support of this view, the incidence of HCV or HBV infection during 10 years (1994-2000) in Japan is very low and estimated at 1.86 (95\% CI 1.06-3.01) or 2.78 (1.87-4.145) per 100,000 person-years [10]. Decreases in undiagnosed HCV and HBV carriers in Japan would have been attributed to increased chances of receiving tests for hepatitis virus infections at health checkups and medical institutions, as well as increased awareness due to educational programs or other healthcare campaigns or screening programs in high-risk individuals. Additionally, there would have been a cohort effect in individuals aged 15-69 years who have shifted by 5 years during the observation period.

The results of the Third National Health and Nutrition Survey (HANES III, 1988-1994) [11] and those of more recent HANES (2001-2002) [6] in the USA are essentially similar with respect to age-specific profiles of $\mathrm{HCV}$ infection, and shifted by 10 years. The incidence of de novo HCV and HBV infections may have decreased substantially both in the USA and Japan, driven partly by the introduction of the nucleic acid amplification test and a more stringent questionnaire on donors to exclude blood donations in the window period of infection [1217]. The national burden of HCV infection has been reported in Great Britain [18], where the prevalence of anti$\mathrm{HCV}$ in hospitalized patients was $3.4 \%$ and that in the first-time blood donors was $0.03 \%$ in the year 2008 .

In spite of many improvements in the control of hepatitis virus infections, there are many HCV and HBV carriers buried in the society who need immediate identification for receiving timely and efficient medical interventions. Treatment of viral hepatitis keeps improving, especially for liver disease induced by HCV. The sustained virological response in the patients infected with $\mathrm{HCV}$ of genotype 1, who have received triple therapy with pegylated interferon, ribavirin and protease inhibitors, has increased to $70 \%$ or higher, from $50 \%$ with the stateof-care therapy with pegylated interferon and ribavirin $[19,20]$. With the advent of new antiviral drugs that will enter the scene in the foreseeable future, the virological response is expected to increase further. There would be 
nothing like early detection of HCV and HBV infections for appropriate and timely medical care to prevent the progression of liver disease. Such a rational strategy will benefit not only patients themselves, but also merit the society and government, which are going to be burdened with ever-increasing morbidity and mortality along with skyrocketing costs.

\section{Acknowledgements}

This work was conducted as a part of the Research on Hepatitis of Ministry of Health, Labour and Welfare in Japan and was supported by grants for Research on Hepatitis of Ministry of Health, Labour and Welfare in Japan. We thank the Japanese Red Cross Society for various supports of this study.

\section{References}

1 World Health Organization: Hepatitis C (Global Alert and Response, 2002). Geneva, WHO, 2002. Updated February 2010 (http:// www.who.int/csr/disease/hepatitis/whocdscsrlyo2003/en/index.html).

2 World Health Organization: Hepatitis B (Factsheet No. 204). Geneva, WHO, Revised August 2008 (http://www.who.int/ mediacentre/factsheets/fs204/en/index.html).

-3 Lok AS: Chronic hepatitis B. N Engl J Med 2002;346:1682-1683.

4 Seeff LB: Natural history of chronic hepatitis C. Hepatology 2002;36:S35-46.

5 Tanaka J, Kumagai J, Katayama K, Komiya Y, Mizui M, Yamanaka R, Suzuki K, Miyakawa Y, Yoshizawa H: Sex- and age-specific carriers of hepatitis B and C viruses in Japan estimated by the prevalence in the $3,485,648$ first-time blood donors during 1995-2000. Intervirology 2004;47:32-40.

-6 Armstrong GL, Wasley A, Simard EP, McQuillan GM, Kuhnert WL, Alter MJ: The prevalence of hepatitis $C$ virus infection in the United States, 1999 through 2002. Ann Intern Med 2006;144:705-714.

7 Yoshizawa H, Tanaka J: A national project for the management of viral hepatitis toward prevention of hepatocellular carcinoma in Japan; in Morrisey RF (ed): International Kilmer Conference Proceedings. Laval, Polyscience Publications, 2004, vol 8, pp 247-264

$\checkmark 8$ Mizui M, Tanaka J, Katayama K, Nakanishi T, Obayashi M, Aimitsu S, Yoshida T, Inoue J, Yokoyama T, Tsuji K, Arataki K, Yamaguchi S, Miura T, Kitamoto M, Takezaki E, Orimen S, Sakata T, Kamada K, Maruhashi A, Tamura T, Nakamura T, Ishida K, Teramen K, Miyakawa Y, Yoshizawa H: Liver disease in hepatitis C virus carriers identified at blood donation and their outcomes with or without interferon treatment: study on 1,019 carriers followed for 5-10 years. Hepatol Res 2007;37:994-1001.
-9 Yoshizawa H: Hepatocellular carcinoma associated with hepatitis $C$ virus infection in Japan: projection to other countries in the foreseeable future. Oncology 2002;62(suppl 1):8-17.

10 Tanaka J, Mizui M, Nagakami H, Katayama K, Tabuchi A, Komiya Y, Miyakawa Y, Yoshizawa $\mathrm{H}$ : Incidence rates of hepatitis $\mathrm{B}$ and $\mathrm{C}$ virus infections among blood donors in Hiroshima, Japan, during 10 years from 1994 to 2004. Intervirology 2008;51:33-41.

11 Wong JB, McQuillan GM, McHutchison JG, Poynard T: Estimating future hepatitis C morbidity, mortality, and costs in the United States. Am J Public Health 2000;90:15621569.

12 Busch MP, Glynn SA, Stramer SL, Strong DM, Caglioti S, Wright DJ, Pappalardo B, Kleinman SH: A new strategy for estimating risks of transfusion-transmitted viral infections based on rates of detection of recently infected donors. Transfusion 2005;45:254-264.

13 Busch MP, Glynn SA, Wright DJ, Hirschkorn D, Laycock ME, McAuley J, Tu Y, Giachetti C, Gallarda J, Heitman J, Kleinman $\mathrm{SH}$ : Relative sensitivities of licensed nucleic acid amplification tests for detection of viremia in early human immunodeficiency virus and hepatitis $\mathrm{C}$ virus infection. Transfusion 2005;45:1853-1863.

14 Yoshikawa A, Gotanda Y, Itabashi M, Minegishi K, Kanemitsu K, Nishioka K: HBV NAT positive [corrected] blood donors in the early and late stages of $\mathrm{HBV}$ infection: analyses of the window period and kinetics of HBV DNA. Vox Sang 2005;88:77-86.

15 Biswas R, Tabor E, Hsia CC, Wright DJ, Laycock ME, Fiebig EW, Peddada L, Smith R, Schreiber GB, Epstein JS, Nemo GJ, Busch MP: Comparative sensitivity of HBV NATs and $\mathrm{HBsAg}$ assays for detection of acute $\mathrm{HBV}$ infection. Transfusion 2003;43:788-798.
16 Kleinman SH, Busch MP: Assessing the impact of HBV NAT on window period reduction and residual risk. J Clin Virol 2006; 36(suppl 1):S23-S29.

17 Yugi H, Mizui M, Tanaka J, Yoshizawa H: Hepatitis B virus screening strategy to ensure the safety of blood for transfusion through a combination of immunological testing and nucleic acid amplification testing - Japanese experience. J Clin Virol 2006; 36(suppl 1):S56-64.

18 http://www.hpa.org.uk/web/HPAweb\& HPAwebStandard/HPAweb_C/125915222116.

19 Hezode C, Forestier N, Dusheiko G, Ferenci P, Pol S, Goeser T, Bronowicki JP, Bourliere M, Gharakhanian S, Bengtsson L, McNair L, George S, Kieffer T, Kwong A, Kauffman RS, Alam J, Pawlotsky JM, Zeuzem S: Telaprevir and peginterferon with or without ribavirin for chronic HCV infection. N Engl J Med 2009;360:1839-1850.

20 McHutchison JG, Everson GT, Gordon SC, Jacobson IM, Sulkowski M, Kauffman R, McNair L, Alam J, Muir AJ: Telaprevir with peginterferon and ribavirin for chronic $\mathrm{HCV}$ genotype 1 infection. N Engl J Med 2009;360: 1827-1838. 